\title{
AURAL REHABILITATION VIA TELEPRACTICE DURING COVID-19: A GLOBAL PERSPECTIVE ON EVOLVING EARLY INTERVENTION PRACTICES
}

\author{
REBECCA CLARIDGE, B.SPTHY, MSPAA, CPSP, LSLS CERT. AVT, \\ NICHOLAS KROLL, BA \\ MED-EL WORLDWIDE HEADQUARTERS, INNSBRUCK, AUSTRIA
}

\begin{abstract}
Introduction: Pre-pandemic, telepractice was not globally implemented despite its effectiveness. Clinicians reported challenges related to technology, confidence, and inadequate resources. Objectives: To document global telepractice, identify current obstacles and measure the impact of a possible solution. The timing of this research facilitated tracking telepractice changes during the pandemic. Methods: Two surveys measured practitioners' experience and attitude towards telepractice. Survey 1 was completed in February-March 2020. Participants then received two specialized lesson kits to trial if desired. Survey 2 was a follow-up after 4-6 weeks. Results: Between surveys, the proportion of participants providing telepractice increased from $47.6 \%$ to $91.7 \%$. The lesson kits were trialled by $74.3 \%$. Their use had a positive impact on three of the top five factors affecting the delivery of telepractice: parent coaching, clinician experience and accessing resources. Conclusion: Telepractice was rapidly adopted globally during the pandemic. The specialized resources were helpful in overcoming some of the barriers to delivery.
\end{abstract}

Keywords: Aural Rehabilitation, Early Intervention, Hearing Impairment, Lesson Kits, Telepractice

The unfolding COVID-19 pandemic had made most in-person visits impossible. People with hearing problems were particularly disadvantaged because compulsory mouth-nose masks have a muting effect on speech and prevent lip reading (Dham et al., 2020; Saile \& Gregori, 2020). This factor could be one of the reasons why cochlear implant users are more afraid of the pandemic than the general population (Aschendorff et al., 2020). Inability to access the required services, such as audio processor repair, and the subsequent troubles in communication led to distress in families with children who are deaf or hard of hearing (Ayas et al., 2020). Interruptions to the recommended aural rehabilitation process can slow down speech-language development in young children (Sharma et al., 2020; Tohidast et al., 2020).

Telepractice allows equitable uninterrupted access to aural rehabilitation services with the help of digital devices (McCarthy et al., 2019b). It has been successfully practiced by providers of aural rehabilitation for close to two decades (Flett, 2001), with the lack of qualified specialists in rural areas being the main driving force behind the adoption of telepractice in America and Australia (Behl et al., 2017; Cason, 2009; McCarthy et al., 2012; Olusanya, 2006). Over the years, telepractice has been shown to be as effective as in-person intervention (Behl et al., 2017; Blaiser et al., 2013; Constantinescu et al., 2014; Wales et al., 2017). In the largest study of its kind to date, Behl et al. (2017), used objective measures to demonstrate that early intervention via telepractice yielded the same auditory skills and language development outcomes as in-person therapy (Behl et al., 2017). In addition, families reported high levels of satisfaction with the service (Blaiser et al., 2013; Cason, 2009; Constantinescu, 2012; Olsen et al., 2012).

Despite the growing need for telepractice and the accumulating evidence of its effectiveness, some practitioners and families remain skeptical about telepractice (Cason et al., 2012; Cole et al., 2019; Fairweather et al., 2016). Lack of specialized training, resources, and reimbursement were named as factors preventing the wider adoption of telepractice (Cason et al., 2012; Dorsey \& Topol, 2016; Keck \& Doarn, 2014; McCarthy et al., 2012). COVID-19 created a unique circumstance wherein telepractice has become a necessity. Most existing studies on telepractice focused on single regions or on multiple services delivered to a mixture of adults and children (American Speech-Language-Hearing Association [ASHA], 2016; Hill \& Miller, 2012; Mohan et al., 2017). Recent studies describing the state of telepractice during the pandemic have the same limitations (Fong et al., 2020). Our primary objective was to assess aural rehabilitation specialists' experience and confidence with telepractice. We hypothesized that provision of appropriate therapy resources could address some of the 
practitioners' reservations about telepractice. Therefore, our secondary objectives were to document the most important factors affecting telepractice delivery and to evaluate the impact of ready-made digital resources (the MED-EL Remote Lesson Kits). The timing of this study provided the opportunity to evaluate changes in these parameters during COVID-19 around the globe.

\section{MATERIALS AND METHODS}

\section{SURVEY DEVELOPMENT}

The two surveys were aimed at rehabilitation specialists who worked with families with children using hearing devices. The survey questions were developed by the authors. Survey 1 contained 17 questions and covered demographics (country and occupation), experience in in-person rehabilitation, experience in telepractice, perception of telepractice, and factors affecting telepractice delivery. Survey 2 contained 16 questions and covered experience in telepractice, perception of telepractice, and the feedback on MED-EL Remote Lesson Kits (MED-EL GmbH, 2020a) from the previous 4 weeks. The MED-EL Remote Lesson Kits consisted of ready-to-use lesson plans, descriptions of teaching strategies, detailed activity instructions, tips on parent coaching, and activity resources in PDF format and PowerPoint slide decks. Participants were informed that these kits would be available as free downloads on the MED-EL Professional Blog on the completion of the research. Most questions were multiple-choice, e.g., "How many years of experience do you have delivering telepractice to families with children who are using hearing technology?" with five possible answers: "none"; "less than 1 year"; "1 to 2 years"; "2 to 5 years"; and "more than 5 years". Answers to some questions were Likert items, e.g., "I feel as confident delivering intervention via telepractice as I do with in-person lessons" with possible answers ranging from "strongly agree" to "strongly disagree" and "not sure." Several questions had open-ended answers, e.g., "Tell us about how you developed or are developing your skills to deliver telepractice," but they were not included in this report. All questions and answer categories are listed in Appendix A.

\section{SURVEY AND REMOTE LESSON KIT DISTRIBUTION}

The Ethics Committee of the Medical University of Innsbruck provided an ethical exemption for this study as it included no medical research on human subjects. On 18 February 2020 the invitation to opt into the research was distributed through LinkedIn and to MED-EL Professional Blog subscribers. In a snowball-sample method, respondents were individually emailed a link to Survey 1 on Microsoft Forms and were encouraged to share the survey with others to minimize selection bias; thus, it was not possible to calculate a response rate. A link to Survey 2 was emailed to the respondents of Survey 1, approximately 4 weeks following their completion of Survey 1 . This time delay between surveys was intended to allow time for telepractice experience, use of the MED-EL Remote Lesson Kits if desired, and then to collect information on how their telepractice intervention had changed. The data were anonymized before being processed. Participation in the research surveys was voluntary. Participants were informed of their rights and company data protection policies, so participating in and submitting the completed questionnaires were considered sufficient evidence of consent. Early access to MED-EL Remote Lesson Kits 1 and 2 was provided following completion of Survey 1, and Remote Lesson Kits 3 and 4 following completion of Survey 2.

\section{STATISTICS}

Statistical analysis was performed using IBM SPSS Statistics Version 24 (IBM, Armonk, New York). Frequency distributions were calculated for all questions except the open-ended ones. Statistical association between answers to different questions was tested using the Chi-Square Test of Independence. For ease of analysis, the answer categories in several questions were collapsed, where appropriate. The affected questions and the collapsed answer categories are listed in Appendix B. Questions 5 and 7 "How many families with children who are using hearing technology do you provide services to in-person/via telepractice?" in Survey 1 did not differentiate between 0 families and 1 family, so these answer categories were excluded from the analysis. 


\section{RESULTS}

\section{DEMOGRAPHICS}

Survey 1 was completed by 273 respondents and 105 of them (38.5\%) also completed Survey 2. Survey 2 was completed by 109 respondents. The respondents of Survey 1 came from 41 countries, including 22 developing countries. The largest number of respondents came from English-speaking countries: $38.8 \%$ came from the USA, $13.2 \%$ from Australia, $6.6 \%$ from the UK, and $4.8 \%$ from Canada. The respondents of Survey 2 came from 29 countries, with the frequency distribution between the countries largely the same as in Survey 1 . In Survey $1,43.6 \%$ of the respondents were speech-language pathologists, $29.3 \%$ were teachers of the Deaf, $11.7 \%$ were audiologists, $12.8 \%$ identified themselves as having a combination of these specializations, and $2.6 \%$ selected "other" as an answer. In Survey 2, the distribution of specializations was very similar (0.8-2.6\% difference between respective categories).

\section{EXPERIENCE IN TELEPRACTICE}

Respondents' experience with in-person intervention and telepractice was assessed in Survey 1 in terms of how much experience (in years) they had, how many families they provided services to, and how many sessions per week they conducted. Results showed that initially the respondents had a lot less experience with telepractice than they did with in-person intervention (Figure 1A). Of the respondents in Survey 1, 92.3\% had more than 1 year of experience with in-person intervention, with $71.8 \%$ having more than 5 years of experience. In contrast, $52.4 \%$, had never delivered telepractice intervention. Of those who had delivered telepractice $(n=130), 43.1 \%$ had less than 1 year of experience and $17.7 \%$ had more than 5 years of experience. Similar distributions were observed in the countries with the largest number of respondents. A similar pattern was observed regarding the number of families the respondents provided services to and the number of sessions they conducted. In addition, $58.2 \%$ of respondents worked with more than 10 families for in-person services and $38.5 \%$ had more than one inperson session per day, whereas $8.4 \%$ worked with more than 10 families remotely and $9.2 \%$ had more than one tele-session per day.

In the time that passed between Survey 1 and Survey 2, the respondents' exposure to telepractice increased dramatically (Figure 1B). Of those who completed Survey 2, 39.4\% tried telepractice for the first time and $36.7 \%$ increased their telepractice intervention. Of the respondents, $11.9 \%$ delivered telepractice intervention only (i.e., no in-person sessions), $8.3 \%$ had not tried telepractice by that time, $27.5 \%$ worked with more than 10 families remotely, and $33.9 \%$ had more than one tele-session per day.

Figure 1

A

\section{Years of experience in telepractice and in-person intervention}

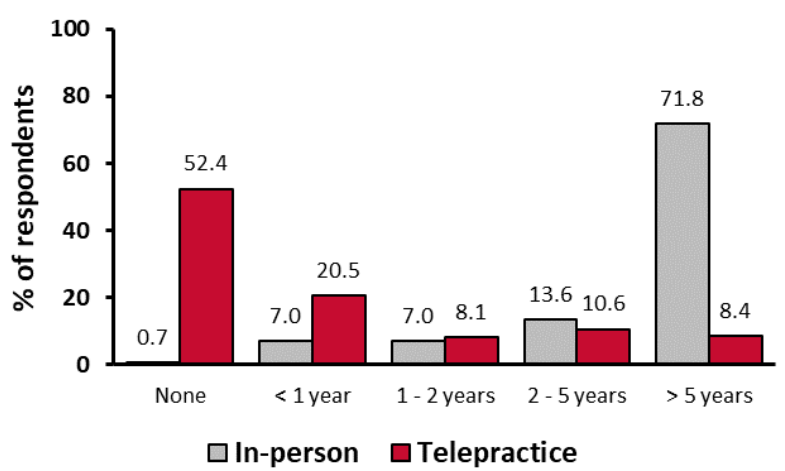

B

\section{Changes in telepractice intervention in the} past 4 weeks

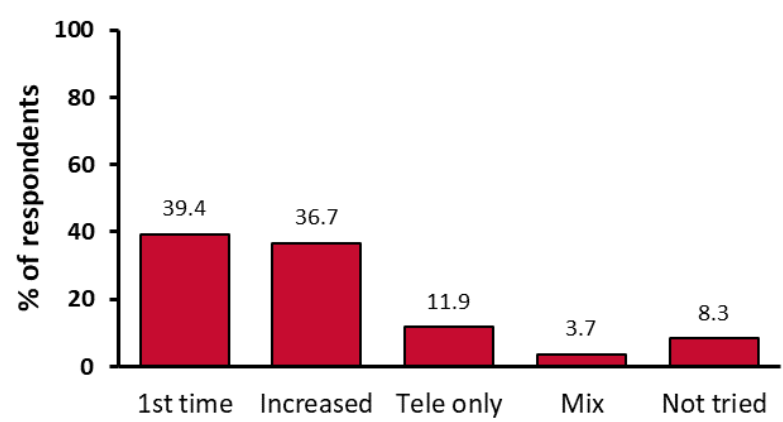

Note. Figure 1.A: Years of Experience in Telepractice (Red) and In-person Intervention (Gray), n = 273; Figure 1.B: Changes in telepractice intervention in the past 4 weeks, $n=109$; Mix: "I provided a mix of telepractice and face-to-face intervention." 


\section{CONFIDENCE}

Respondents' confidence with telepractice was assessed in terms of their degree of agreement with the statement "I feel as confident delivering intervention via telepractice as I do with in-person lessons." We assumed that people felt more confident with in-person intervention than with telepractice, therefore those who agreed with the "as confident" statement must have been more confident with telepractice than those who disagreed. In Survey 1 , the respondents were equally likely to agree $(35.2 \%)$ and to disagree $(35.5 \%)$ with the statement. Of the respondents, $19.8 \%$ selected the answer "neutral" and $9.5 \%$ were not sure. Confidence was associated with experience in telepractice $\left(x^{2}: 55.219 ; \mathrm{df}=6 ; \mathrm{p}<0.001\right)$. The respondents with more than 1 year of experience in telepractice were much more likely to feel confident $(64.9 \%)$ than the ones without any experience $(21.7 \%)$ (Figure 2A). The opposite was also true: the inexperienced respondents were more likely to be less confident $(44.8 \%)$ and unsure $(16.1 \%)$ than the experienced ones $(14.9 \%$ and $2.7 \%$, respectively). Confidence level was similarly associated with the number of families in telepractice $\left(X^{2}: 37.465 ; \mathrm{df}=12 ; p<0.001\right)$ and with the frequency of tele-sessions $\left(x^{2}: 41.985 ; \mathrm{df}=12 ; p<0.001\right)$.

In Survey 2, the respondents were already more than twice as likely to agree with the statement about confidence than to disagree (54.1\% and $21.1 \%)$. Of the respondents, $17.4 \%$ answered "neutral" and $7.4 \%$ were not sure. Of those who increased their telepractice intervention, $77.5 \%$ reported feeling confident with it. Even among the first-timers, the largest proportion of respondents $(37.2 \%)$ already felt as confident with telepractice as with in-person intervention. Confidence was also associated with how often the kits had been used in the previous 4 weeks $\left(x^{2}: 28.363 ; \mathrm{df}=9 ; p=0.001\right)$. The respondents who had used the kits daily were a lot more likely to feel confident $(71.4 \%)$ than those who had not used them at all $(32.1 \%)$ (Figure $2 \mathrm{~B})$. There was no significant association between confidence and the number of families in telepractice $\left(X^{2}: 22.374 ; \mathrm{df}=15 ; p=0.098\right)$ or the frequency of tele-sessions in the past 4 weeks $\left(x^{2}: 20.802 ; \mathrm{df}=12 ; p=0.053\right)$. There was no apparent sampling bias, because the 105 returning respondents were representative of the total population in Survey 1 and were similar to non-returners in terms of their initial confidence levels $(1.9-8.2 \%$ differences between respective answer categories among returners and non-returners) (Figure $3 \mathrm{~A})$.

\section{A}
"I feel as confident delivering intervention via telepractice as I do with in-person lessons" by experience in years

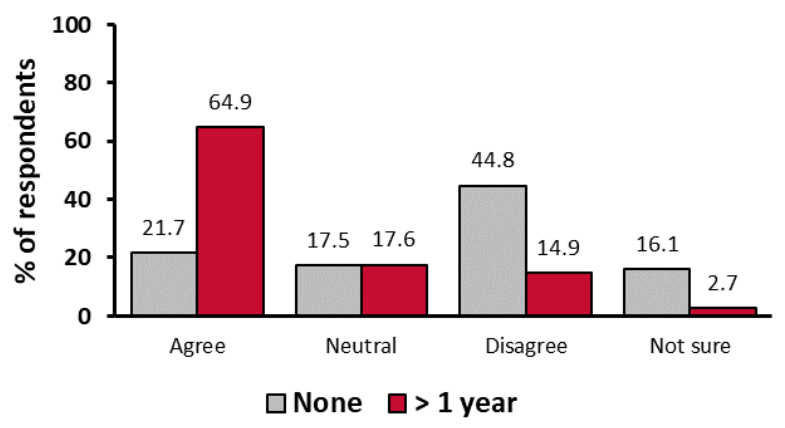

B
"I feel as confident delivering intervention via telepractice as I do with in-person lessons" by frequency of kit use

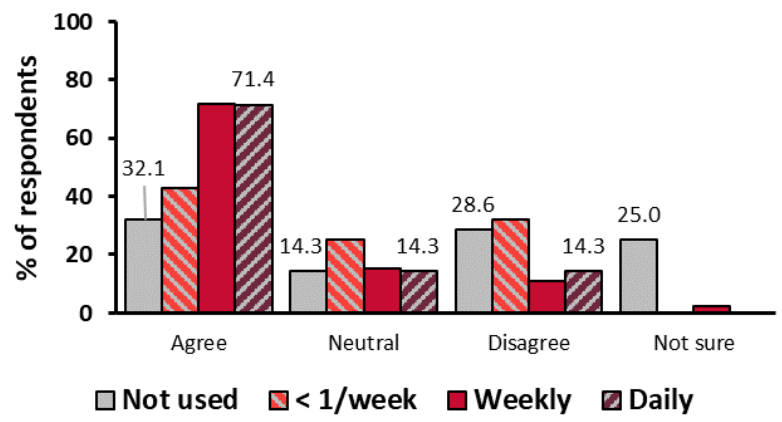

Note. Figure 2.A: Confidence with telepractice delivery according to clinician's experience in telepractice (gray: no experience, $n=143$; red: more than 1 year of experience, $n=74$ ); Figure 2.B: Confidence with telepractice delivery after 4 weeks according to the frequency of the MED-EL Remote Lesson Kit use, (gray: not used, $n=28$; light red, striped: less than once per week, $n=28$; red: weekly, $n=46$; dark red, striped: daily, $n=7$ ). 
Figure 3

A

\section{Confidence level in Survey 1 among returners and non-returners}

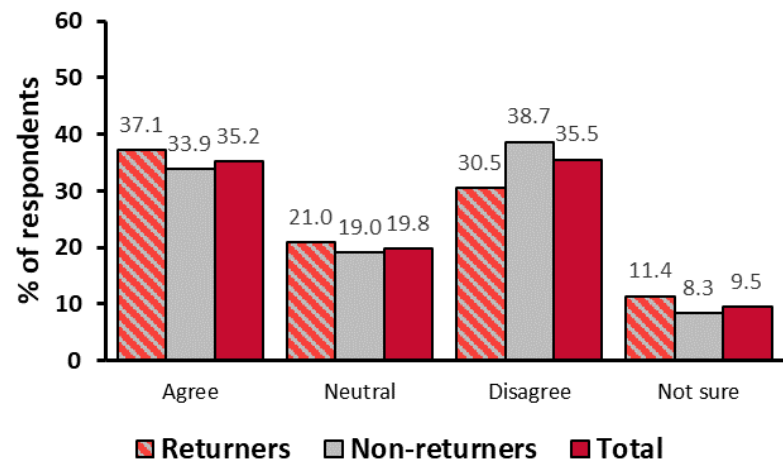

\section{Using the same resources in S1 among returners and non-returners}

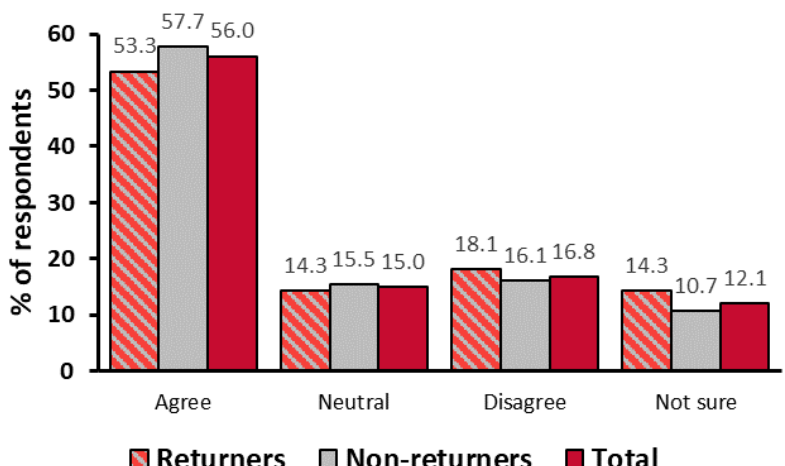

Note. Figure 3.A: Confidence with telepractice delivery in Survey 1 among returners (light red, striped, $n=105$ ), non-returners (gray, $n=168$ ) and the total number of respondents (red, $n=273$ ); Figure 3.B: Resource utilization in Survey 1 among returners (light red, striped, $n=105$ ), non-returners (gray, $n=168$ ) and the total number of respondents (red, $\mathrm{n}=273$ ).

\section{OUTCOMES OF TELEPRACTICE}

In Survey 1, when asked how telepractice outcomes compared to in-person therapy outcomes, $4.4 \%$ of respondents expected them to be better, $41.4 \%$ to be the same, $20.5 \%$ to be poorer, and $33.7 \%$ were not sure. Again, the distribution varied substantially depending on the experience (Figure $4 \mathrm{~A}$ ): $30.8 \%$ of the respondents with no experience in telepractice expected it to have the same outcomes and $51.0 \%$ were not sure, compared to $64.9 \%$ of respondents with more than 1 year of experience who expected the outcomes to be the same and $8.1 \%$ who were not sure. The association between outcome expectations and experience was significant $\left(X^{2}: 53.030 ; \mathrm{df}\right.$ $=6 ; p>0.001)$. This variable was also associated with confidence $\left(x^{2}: 59.316 ; d f=9 ; p<0.001\right)$. The more confident respondents were more likely to expect the outcomes to be the same $(67.7 \%)$ and less likely to expect them to be poorer $(9.4 \%)$ or be unsure $(15.6 \%)$. The opposite was true for the less confident respondents: $24.7 \%$ expected the outcomes to be the same, $32.0 \%$ to be poorer, and $42.3 \%$ were not sure.

In Survey 2, when asked about the outcomes of telepractice when the MED-EL Remote Lesson Kits were used, the respondents were more likely to expect positive outcomes: $56.9 \%$ expected them to be the same, $10.1 \%$ to be poorer, and $29.3 \%$ were not sure. Respondents who had used the kits any number of times in the previous 4 weeks were more likely to expect the outcomes to be the same than those who had not (Figure 4B). The association between these two variables was significant $\left(X^{2}: 25.040 ; d f=9 ; p=0.003\right)$. Outcome expectations were associated with confidence the same way as in Survey $1\left(x^{2}: 21.196 ; d f=9 ; p=0.012\right)$ : the more confident respondents were a lot more likely to expect the outcomes of telepractice with the kits to be the same $(71.2 \%)$ compared to the less confident ones (43.5\%). Again, no apparent sampling bias was observed (3.9 $-5.2 \%$ differences between respective answer categories among returners and non-returners).

\section{USING THE SAME RESOURCES}

In Survey 1, the effectiveness of resources used in telepractice was assessed in terms of respondents' degree of agreement with the statement "I can (or I think I could) effectively use the same therapy resources for in-person and telepractice sessions." Of the respondents, $56.0 \%$ agreed that they could (or thought they could) use the same resources during both in-person and remote sessions, while $16.9 \%$ disagreed. Notably, among the respondents with more than 1 year of experience in telepractice, the proportion of those who agreed was nearly the same (56.0\% vs. $58.1 \%)$, but the proportion of those who disagreed was larger $(16.9 \%$ vs. $28.4 \%)$ (Figure $5 A)$. The association between resource utilization and experience was significant $\left(X^{2}: 30.123 ; d f=6 ; p<0.001\right)$. Resource utilization was also associated with the number of families in telepractice $\left(x^{2}: 22.354 ; \mathrm{df}=12 ; p=\right.$ $0.034)$ and with the frequency of tele-sessions $\left(x^{2}: 35.333 ; \mathrm{df}=12 ; p<0.001\right)$. The respondents who were 
confident with telepractice were more likely $(72.9 \%)$ to agree that the same resources could be used; $13.5 \%$ of them disagreed. The association between resource utilization and confidence was significant $\left(x^{2}: 57.409 ; \mathrm{df}=9\right.$; $\mathrm{p}<0.001)$.

In Survey 2, the distribution of answers changed: fewer respondents overall agreed that they could use the same resources $(29.4 \%)$, and more disagreed (38.5\%). Of the respondents who used the kits daily, $57.1 \%$ agreed that the same resources could be used, compared to $28.6 \%$ who disagreed (Figure 5B). The association between resource utilization and how often the kits were used was significant $\left(X^{2}: 19.840 ; d f=9 ; p=0.019\right)$. As in Survey 1 , the responses on resource utilization were associated with confidence $\left(x^{2}: 27.580 ; \mathrm{df}=9 ; p=0.001\right)$, but this time the respondents were much more likely to disagree with the statement or answer "neutral." A total of $35.6 \%$ of the more confident respondents and $60.9 \%$ of the less confident respondents disagreed that they could use the same resources. Again, no sampling bias was observed (1.2-4.4\% differences between respective answer categories among returners and non-returners) (Figure 3B).

Figure 4

\section{"Therapy outcomes from telepractice are likely to be..." by experience in years}

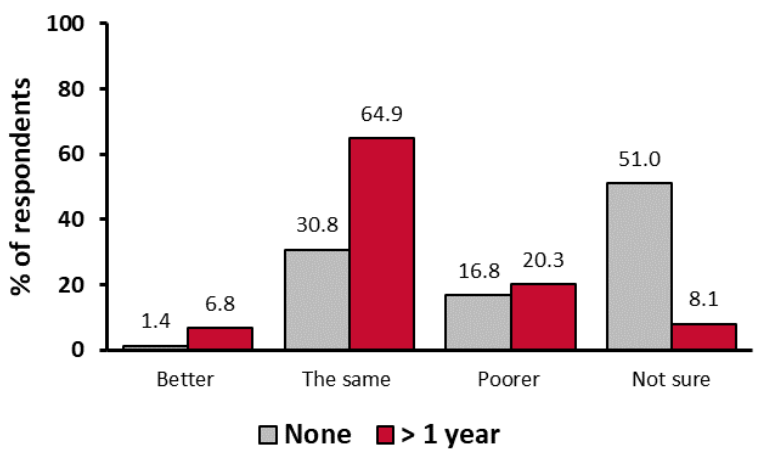
"Therapy outcomes from telepractice are
likely to be..." by frequency of kit use

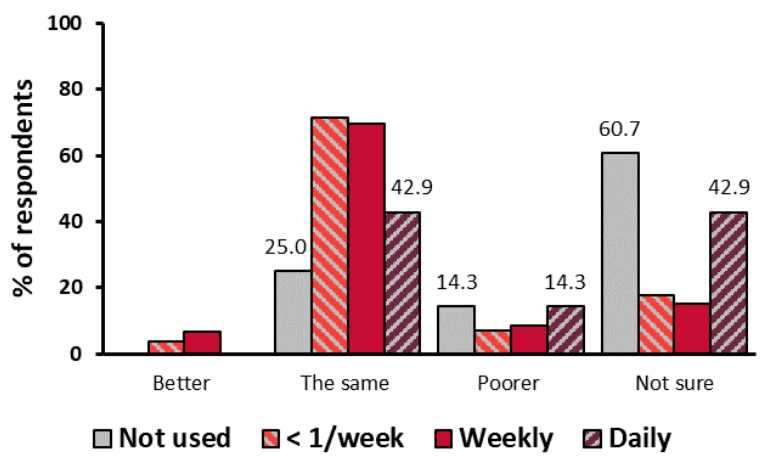

Note. Figure 4.A: Telepractice outcome expectations according to clinician's experience in telepractice (gray: no experience, $n=143$; red: more than 1 year of experience, $n=74$ ); Figure 4.B: Telepractice outcome expectations according to the frequency of the MED-EL Remote Lesson Kit use, (gray: not used, $n=28$; light red, striped: less than once per week, $n=28$; red: weekly, $n=46$; dark red, striped: daily, $n=7$ ).

Figure 5

A
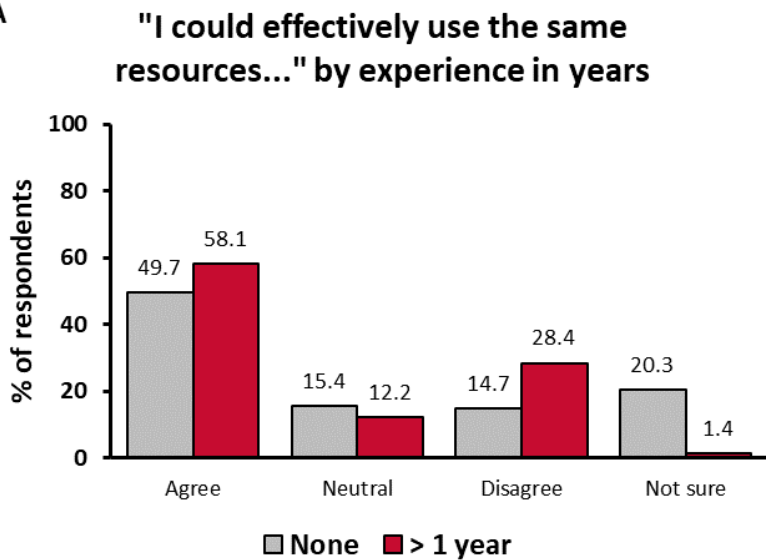

B
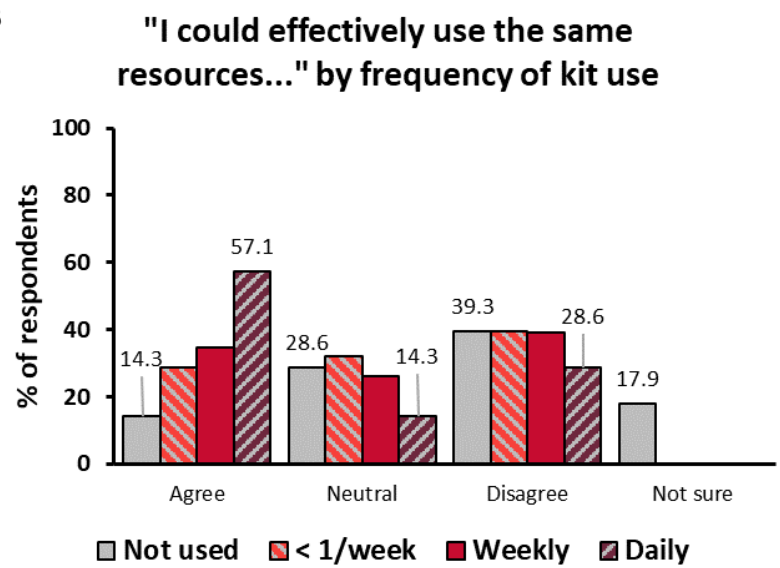

Note. Figure 5.A: Resource utilization according to clinician's experience in telepractice (gray: no experience, $n=$ 143; red: more than 1 year of experience, $n=74$ ); Figure 5.B: Resource utilization expectations according to the frequency of the MED-EL Remote Lesson Kit use, (gray: not used, $n=28$; light red, striped: less than once per week, $n=28$; red: weekly, $n=46$; dark red, striped: daily, $n=7$ ). 


\section{FACTORS AFFECTING TELEPRACTICE DELIVERY}

In Survey 1, the respondents were asked to evaluate the impact different factors might have on the telepractice delivery. The factors were ordered according to how many respondents rated them as having a "significant" or "very significant" impact (Figure 6.A). The top 5 factors were: internet connectivity (72.2\%), child management $(72.0 \%)$, clinician use of parent coaching strategies $(70.3 \%)$, clinician's experience in telepractice $(65.6 \%)$, and accessing or developing appropriate therapy resources $(65.6 \%)$. Child management came first among the respondents with no experience in telepractice $(74.1 \%)$ and only fifth among those with more than 1 year of experience $(60.1 \%)$ (Figure $6 \mathrm{~B})$. The association between this factor and experience was significant $\left(\mathrm{X}^{2}\right.$ : 16.379; $\mathrm{df}=8 ; \mathrm{p}=0.037)$. In contrast, clinician use of parent coaching strategies was fourth in the no-experience group $(67.8 \%)$ and first in the experienced group $(78.4 \%)$, but this association did not reach significance $\left(x^{2}\right.$ : 12.361; $\mathrm{df}=8 ; \mathrm{p}=0.136)$. The factor "accessing or developing appropriate therapy resources" was associated with experience $\left(x^{2}: 23.715 ; \mathrm{df}=8 ; p=0.003\right)$ : it was third in the no-experience group $(69.9 \%)$ and only sixth in the experienced group (55.4\%).

In Survey 2, the respondents were asked to evaluate the impact of the MED-EL Remote Lesson Kits provided on delivery of telepractice. The top 5 factors that the respondents rated as having a "positive" or "very positive" impact were: accessing or developing appropriate therapy resources (78.9\%), clinician use of parent coaching strategies $(66.1 \%)$, clinician's experience in telepractice $(62.4 \%)$, information sharing $(61.5 \%)$, and cost of therapy resources (55.0\%). Therefore, the kits were most helpful for 3 of the top 5 factors important for telepractice delivery.

Figure 6 kits on them

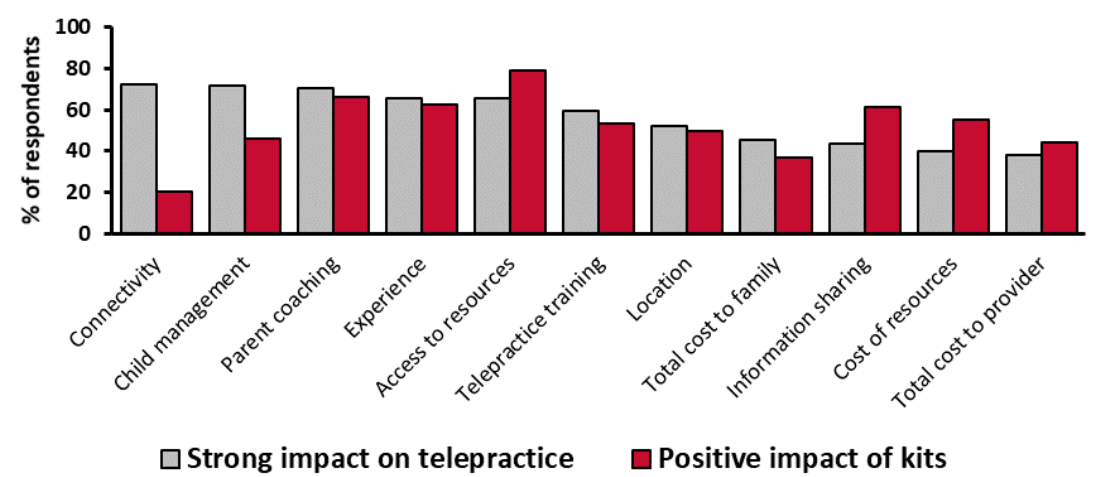

B
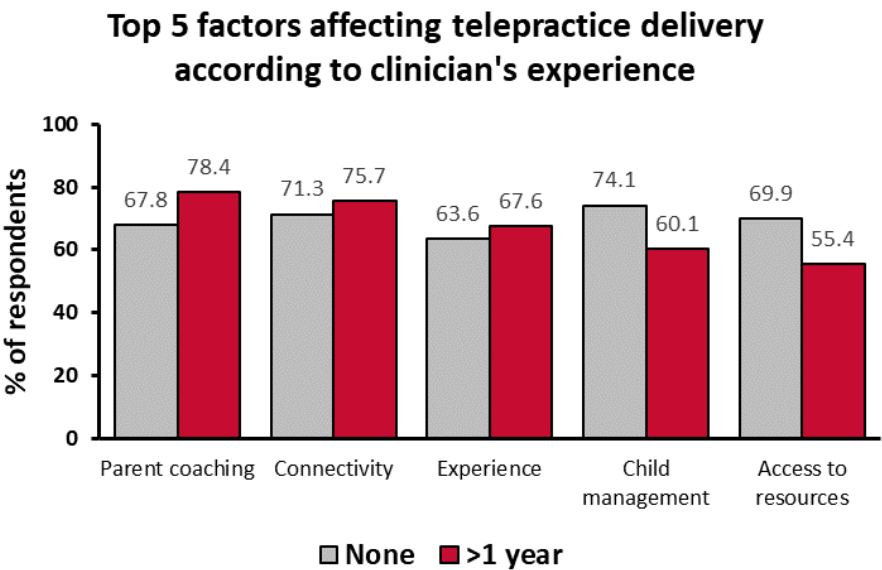

Note. Figure 6.A: Proportion of respondents believing that these factors have a strong impact on telepractice delivery (gray, $n=273$ ) and that they were positively affected by the MED-EL Remote Lesson Kits (red, $n=109$ ); Figure 6.B: Top 5 factors having a strong impact on telepractice delivery according to clinician's experience with telepractice (gray: no experience, $n=143$; red: more than 1 year of experience, $n=74$ ). 


\section{DISCUSSION}

We investigated the perception of telepractice among 273 rehabilitation specialists from 41 countries, including 22 developing countries (Survey 1) (United Nations, 2020). Previous studies which focused specifically on remote aural rehabilitation had much smaller samples and were limited to a single center or country (ASHA, 2016; Behl et al., 2017; Blaiser et al., 2013; Fong et al., 2020; McCarthy et al., 2020; Mohan et al., 2017). Survey 1 revealed that more than half of the respondents $(52.4 \%)$ had not tried telepractice at the start of the COVID-19 pandemic. In the USA, the country with the largest number of respondents, $46.2 \%$ had tried telepractice, half of whom had been delivering it for more than 1 year. In comparison, a survey conducted by the American SpeechLanguage-Hearing Association (ASHA) in 2016 revealed that $63.7 \%$ of respondents had experience in telepractice, and almost $82 \%$ of them had more than 1 year of experience, but $11.5 \%$ provided aural rehabilitation via telepractice (ASHA, 2016).

The COVID-19 pandemic has had a strong impact on the delivery of medical services around the world (Fong et al., 2020; Madden et al., 2020; Saunders \& Roughley, 2020; Yellowlees et al., 2020). One of our respondents wrote: "Our practice went from $0 \%$ teletherapy to $100 \%$ teletherapy in less than a week." The uniqueness of our study is that it provides a longitudinal analysis of the short-term effects on global telepractice among aural rehabilitation specialists provided with ready-made telepractice resources during the pandemic. Survey 2 revealed a surge in telepractice exposure in a matter of weeks: by May 2020,39.4\% of the returning respondents had tried telepractice for the first time, $36.7 \%$ had increased the amount of telepractice intervention they offered, and only $8.3 \%$ had not tried telepractice. Of the respondents, $27.5 \%$ were now offering telepractice to more than 10 families with children and $33.9 \%$ had more than one tele-session per day. Both proportions were below $10 \%$ in February 2020. An increase in telepractice due to the pandemic was also reported in Hong Kong: $35 \%$ of 135 speech-language pathologists there were providing telepractice at the time of the survey in February-March 2020, and $72.3 \%$ of those who had delivered telepractice had started in the previous 3 months (Fong et al., 2020).

Survey 1 identified that confidence with telepractice delivery was associated with experience. The respondents with more than 1 year of experience were three times more likely to feel as confident with telepractice as with in-person intervention. This relationship is supported by the findings of the ASHA survey, which revealed that on average only $1.6 \%$ of respondents felt completely unprepared for different aspects of telepractice at the time of the survey, whereas $14.5 \%$ felt so when they started delivering telepractice intervention (ASHA, 2016). Although it is normal to feel less confident with new tasks, our second survey revealed that confidence grew in a matter of weeks $(35.2 \%$ in Survey 1 vs. $54.1 \%$ in Survey 2$)$. Of the respondents, $74.3 \%$ reported trialing the MED-EL Remote Lesson Kits during this time. Of the rehabilitation specialists who used the kits weekly or daily, $71.7 \%$ reported feeling confident with telepractice, compared to $32.1 \%$ of those who did not use the kits. The largest proportion of confident respondents was among those who increased their telepractice intervention (77.5\%), but even among the first-timers it was quite large (37.2\%). This increase is more likely to be attributable to the changes that occurred between the two surveys than to the sampling bias, because the initial level of confidence was similar among returners and non-returners. Both the rising exposure to telepractice and the provision of ready-made resources could have contributed to the increase in confidence, but the design of the study does not allow one to determine the exact contribution of each factor.

The respondents appeared quite skeptical about the outcomes of telepractice despite the accumulating evidence in favor of its effectiveness (Behl et al., 2017; Blaiser et al., 2013; Constantinescu et al., 2014; Wales et al., 2017). Although the largest proportion expected the outcomes to be the same as with in-person intervention $(41.4 \%), 33.7 \%$ were not sure and $20.5 \%$ expected them to be poorer. Of the American practitioners, $40 \%$ were concerned about the quality of early intervention services for children with disabilities if they were delivered via telepractice (Cason et al., 2012). Of speech-language pathologists in Hong Kong, $40.9 \%$ indicated "questionable effectiveness" as one of the reasons for not trying telepractice (Fong et al., 2020). In the Hong Kong study, 51.1\% of those who tried telepractice thought it was less effective than in-person intervention and $27 \%$ agreed that "telepractice is based on current evidence-based practice and is at least equivalent to standard clinical care". Interestingly, an Australian study revealed that the self-assessed use of family-centered practices did not differ between the practitioners who delivered telepractice and those who delivered in-person intervention. The questionnaire included domains encompassing general and specific information, communication, and interpersonal sensitivity (McCarthy et al., 2020).

Outcome expectations were modified by experience in telepractice following the provision of the MED-EL Remote Lesson Kits. The respondents of Survey 2 who used the Lesson Kits were more positive about the outcomes of telepractice: $66.0 \%$ of those who used the kits weekly or daily expected the outcomes to be the same and $9.4 \%$ of them expected the outcomes to be poorer. In addition, the respondents with more than 1 year of experience were about twice as likely to expect the outcomes to be the same and over 6 times less likely to be unsure about this question compared to the respondents who had not tried telepractice. Practitioners with higher 
confidence were much less skeptical and unsure about the outcomes of telepractice: $9.4 \%$ of them predicted that the outcomes would be poorer compared to $32 \%$ of those who felt less confident. So, the availability of appropriate resources and gaining experience in telepractice could make practitioners more confident of themselves and of the effectiveness of this intervention mode.

In Survey 1, we identified the factors thought to have the greatest impact on telepractice delivery. A total of 11 factors were described as having a significant or very significant impact by $38.1-72.2 \%$ of the respondents. Most of the respondents (72.2\%) were concerned about connectivity issues. Indeed, this factor is often mentioned as one of the difficulties encountered during tele-sessions (Cole et al., 2019; Fairweather et al., 2016; McCarthy et al., 2019b; Yang et al., 2020). However, Keck and Doarn (2014) demonstrated the feasibility of telepractice using different digital devices across a wide range of speech-language disorders. According to their review, disturbances during real-time videoconferencing had not led to discontinuation of intervention and these could be alleviated using asynchronous technology. It is also important to note that connectivity issues may present significant challenges to telepractice that are difficult for practitioners to directly resolve, but technology for teleconferencing and global connectivity is continually improving. Especially considering shifts to remote working and video conferencing during the pandemic, connectivity challenges may become less of a burden as technology improves and user experience with these platforms increases.

Child attention and behavior management was the second most impactful factor, selected by $72.0 \%$ of the respondents. Interestingly, it ranked first among the Survey 1 respondents with no experience in telepractice and only fifth among the respondents with more than 1 year of experience. Although some differences between in-person and tele-sessions are inevitable, interaction strategies can be successfully adapted by the practitioner (Ekberg et al., 2019). Moreover, some parents reported that tablets and other digital devices made their children more engaged during the session (Fairweather et al., 2016).

Approximately $78 \%$ of experienced respondents in Survey 1 identified clinician use of parent coaching strategies as the most impactful factor on the delivery of telepractice. The MED-EL Remote Lesson Kits contained guidance on parent coaching and $79 \%$ of Survey 2 practitioners who trialed the kits reported that the resources helped them with this important aspect of telepractice. Providing coaching to parents could be key to child management because child-parent interactions come to the forefront in telepractice intervention (Behl et al., 2017; Korfmacher et al., 2008; McCarthy et al., 2019a). Practitioners observe and provide feedback to parents more often during tele-sessions than during in-person visits (Olsen et al., 2012; Stredler-Brown, 2017), which leads to higher parental involvement and engagement (Blaiser et al., 2013; Cole et al., 2019). According to the international consensus statement (Moeller et al., 2013), such family-centered early intervention behaviors are best practice for families who have children with hearing impairment. The results of our study support this idea.

Our hypothesis that provision of specialized therapy resources could be beneficial for practitioners was confirmed. Accessing or developing such resources was the fifth most impactful factor (65.6\%), and most respondents $(78.9 \%)$ reported that the specialized kits provided by MED-EL were very useful. Practitioners with experience in telepractice recognized the need for specialized resources more than those who had not tried telepractice. In a matter of 4 weeks, following the provision of the MED-EL Remote Lesson Kits and after most respondents had introduced tele-sessions to their practice, the overall proportion of respondents who felt they could not use the same resources in telepractice as in in-person therapy had more than doubled. We believe that this increase, like the increase in confidence, can be attributed to the greater exposure to telepractice in combination with the use of the MED-EL Remote Lesson kits that occurred between the two surveys and not to the sampling bias because the initial resource utilization was very similar among returners and non-returners. Interestingly, the practitioners who used the kits more often were more likely to agree that the same resources could be used, which could be an indication that it felt easier to adapt the specialized resources to the familiar inperson setting than the other way round. These kits were adapted from earlier Themed Lesson Kits (MED-EL $\mathrm{GmbH}, 2020 b$ ) that were designed for in-person therapy, so this may also be a reason why the Remote Lesson Kits could be seen as useful for both types of intervention. Our findings are in line with the literature: lack of training, resources, and support was the second most cited reason for not providing telepractice among the practitioners in Hong Kong (Fong et al., 2020). In India, 83.9\% of professionals delivering various speechlanguage therapies believed that the available resources were not sufficient and appropriate for telepractice (Mohan et al., 2017).

According to the results of our surveys, setup and ongoing costs to the family and to the practitioner were least likely to impact telepractice delivery. Fong et al. (2020) also found that only $5.7 \%$ of the respondents thought that the costs of telepractice were too high (Fong et al., 2020). Nonetheless, technology expenses and the lack of reimbursement could make telepractice less cost-effective and therefore less attractive (McCarthy et al., 2019b). We did not explicitly ask about this factor in our surveys, but the lack of funding is consistently reported as a barrier to telepractice adoption across literature (Cason et al., 2012; Dorsey \& Topol, 2016; Saunders \& 
Roughley, 2020; Smith et al., 2020). Traditionally, telepractice is covered by insurance only in rural areas in countries like the USA and Australia (McCarthy et al., 2012), but even people living in urban centers would benefit from access to remote services, as the COVID-19 pandemic has shown (Smith et al., 2020). Furthermore, telepractice would likely reduce travel burdens and associated costs for patients, which could make aural rehabilitation more easily accessible. However, as with any professional rehabilitation session, telepractice sessions still require significant time and effort from providers. The expected time commitment by practitioners for delivering a telepractice session compared to an in-person session is a topic that has been identified as requiring further investigation (McCarthy et al., 2019b). Preliminary findings suggest that the time commitment is at least equivalent to in-person sessions. Therefore, it would be essential for healthcare systems to provide appropriate funding options for telepractice. Our findings of the rapid increase in telepractice exposure around the world highlight the importance of introducing flexible funding strategies that would allow continuous service delivery, especially for patients for whom timely care is crucial for their development or health (Sharma et al., 2020; Tohidast et al., 2020).

Our study had several limitations. Firstly, the surveys focused in detail on how rehabilitation specialists perceived telepractice, but it is also important to incorporate the family's perspective into the picture. Previous studies consistently reported high levels of satisfaction with telepractice among both practitioners and parents (Cason, 2009; Constantinescu, 2012; McCarthy et al., 2019b). It would be interesting to investigate how attitudes to telepractice changed among patients and whether those who had access to telepractice during the pandemic were satisfied with the service. Secondly, although our surveys were longitudinal, no causality could be inferred from their results. Significant associations between telepractice experience and the practitioner's confidence and outcome expectations could be of either directionality. Controlled experiments could establish the exact nature of these relationships in the future. Lastly, non-native English speakers could have had some difficulties answering questions in English. However, we did not expect it to affect the results because most of the respondents came from English-speaking countries and the questions were formulated in relatively simple English.

\section{CONCLUSION}

COVID-19 has led to a rapid increase in telepractice intervention provided to families with children with impaired hearing. This increase was associated with growing confidence and improved outcome expectations, particularly in practitioners who used the MED-EL Remote Lesson Kits. These ready-made resources containing detailed lesson plans and guidance on parent coaching had a positive impact on some of the most important factors affecting telepractice delivery. These findings may encourage the provision of more telepractice specific resource development, training opportunities and the development of comprehensive reimbursement strategies that would support wider telepractice adoption. Even beyond the scope of the COVID-19 pandemic, the benefits of telepractice could help support more equitable access to effective aural rehabilitation services around the world.

\section{CONFLICTS OF INTEREST}

All authors and contributors are employees of MED-EL and as such receive a salary. No additional finances are gained from users accessing or using materials described in the article or on the website. All materials described in the article are now available as free downloads on the MED-EL Professional Blog. The authors and their employer receive no financial gain from any increases in traffic to, or downloads from the blog. At the time of the research the kits were released to study participants only with the intent to gather feedback on their use. Participation was a voluntary opt in response to invitations published through the MED-EL Professional Blog and MED-EL Linkedln. Owing to this initial recruitment method participants had previous social media connections with MED-EL and this may present a selection bias. Initial recruits were encouraged to share the link to the Survey 1 to join the study resulting in a snowball sample diluting the sample bias. It was not possible to identify percentage of participants with a prior social media connection with MED-EL. All respondents were accepted as participants until closing date May 2020. Participants were free to discontinue the study at any time by choosing to not complete either survey or choosing to not download the Remote Lesson Kits. Use of the Remote Lesson Kits was optional. 


\section{ACKNOWLEDGMENTS}

The authors appreciate the meaningful contributions made to this study by: Edda Amann, Dr. rer.nat. MPH, Ilona Anderson, PhD, Angelina Gurkina, MSc., and Aneesha Pretto, PhD, CCC-SLP, LSLS Cert. AVT.

\section{REFERENCES}

American Speech-Language-Hearing Association. (2016). 2016 SIG 18 telepractice survey results.

Aschendorff, A., Arndt, S., Kroger, S., Wesarg, T., Ketterer, M. C., Kirchem, P., Pixner, S., Hassepass, F., \& Beck, R. (2020). Quality of cochlear implant rehabilitation under COVID-19 conditions. HNO. https://doi.org/10.1007/s00106-020-00923-Z

Ayas, M., Ali Al Amadi, A. M. H., Khaled, D., \& Alwaa, A. M. (2020). Impact of COVID-19 on the access to hearing health care services for children with cochlear implants: a survey of parents. F1000Res, 9, 690. https://doi.org/10.12688/f1000research.24915.1

Behl, D. D., Blaiser, K., Cook, G., Barrett, T., Callow-Heusser, C., Brooks, B. M., Dawson, P., Quigley, S., \& White, K. R. (2017). A multisite study evaluating the Benefits of early intervention via telepractice. Infants \& Young Children, 30(2), 147-161. https://doi.org/10.1097/iyc.0000000000000090

Blaiser, K. M., Behl, D., Callow-Heusser, C., \& White, K. R. (2013). Measuring costs and outcomes of tele-intervention when serving families of children who are Deaf/hard-of-hearing. International Journal of Telerehabilitation, 5(2), 3-10. https://doi.org/10.5195/ijt.2013.6129

Cason, J. (2009). A pilot telerehabilitation program: delivering early intervention services to rural families. International Journal of Telerehabilitation, 1(1), 29-38. https://doi.org/10.5195/ijt.2009.6007

Cason, J., Behl, D., \& Ringwalt, S. (2012). Overview of States' Use of Telehealth for the Delivery of Early Intervention (IDEA Part C) Services. International Journal of Telerehabilitation, 4(2), 39-46. https://doi.org/10.5195/IJT.2012.6105

Cole, B., Pickard, K., \& Stredler-Brown, A. (2019). Report on the use of telehealth in early intervention in Colorado: Strengths and challenges with telehealth as a service delivery method. International Journal of Telerehabilitation, 11(1), 33-40. https://doi.org/10.5195/ijt.2019.6273

Constantinescu, G. (2012). Satisfaction with telemedicine for teaching listening and spoken language to children with hearing loss. Journal of Telemedicine and Telecare, 18(5), 267-272. https://doi.org/10.1258/jtt.2012.111208

Constantinescu, G., Waite, M., Dornan, D., Rushbrooke, E., Brown, J., McGovern, J., Ryan, M., \& Hill, A. (2014). A pilot study of telepractice delivery for teaching listening and spoken language to children with hearing loss. Journal of Telemedicine and Telecare, 20(3), 135-140. https://doi.org/10.1177/1357633X14528443

Dham, R., Arumugam, S. V., Dharmarajan, S., Sunil, M., Paramasivan, V. K., \& Kameswaran, M. (2020). Interrupted cochlear implant habilitation due to COVID-19 pandemic-ways and means to overcome this. International Journal of Pediatric Otorhinolaryngology 138, 110327. 10.1016/j.ijporl.2020.110327

Dorsey, E. R., \& Topol, E. J. (2016). State of telehealth. New England Journal of Medicine, 375(2), $154-161$. https://doi.org/10.1056/NEJMra1601705

Ekberg, S., Danby, S., Theobald, M., Fisher, B., \& Wyeth, P. (2019). Using physical objects with young children in face-to-face and telehealth speech and language therapy. Disability and Rehabilitation, 41, 1664 - 1675. https://doi.org/10.1080/09638288.2018.1448464

Fairweather, G. C., Lincoln, M. A., \& Ramsden, R. (2016). Speech-language pathology teletherapy in rural and remote educational settings: Decreasing service inequities. International Journal of Speech-Language Pathology, 18(6), 592-602. https://doi.org/10.3109/17549507.2016.1143973

Flett, O. (2001). Working with families of young hearing impaired children from a distance: The Taralye experience. Australian Journal of Education of the Deaf , 7, 41-42.

Fong, R., Tsai, C. F., \& Yiu, O. Y. (2020). The implementation of telepractice in speech language pathology in Hong Kong During the COVID-19 pandemic. Telemedicine and e-Health. https://doi.org/10.1089/tmj.2020.0223

Hill, A., \& Miller, L. E. (2012). A survey of the clinical use of telehealth in speech-language pathology across Australia. Journal of Clinical Practice in Speech-Language Pathology, 14(3), 110-117.

Keck, C. S., \& Doarn, C. R. (2014). Telehealth technology applications in speech-language pathology. Telemedicine and eHealth, 20(7), 653-659. https://doi.org/10.1089/tmj.2013.0295

Korfmacher, J., Green, B., Staerkel, F., Peterson, C., Cook, G., Roggman, L., Faldowski, R. A., \& Schiffman, R. (2008). Parent involvement in early childhood home visiting. Child \& Youth Care Forum, 37(4), 171-196. https://doi.org/10.1007/s10566$\underline{008-9057-3}$ 
Madden, N., Emeruwa, U. N., Friedman, A. M., Aubey, J. J., Aziz, A., Baptiste, C. D., Coletta, J. M., D'Alton, M. E., Fuchs, K. M., Goffman, D., Gyamfi-Bannerman, C., Kondragunta, S., Krenitsky, N., Miller, R. S., Nhan-Chang, C. L., Saint Jean, A. M., Shukla, H. P., Simpson, L. L., Spiegel, E. S., Yates, H. S., Zork, N., \& Ona, S. (2020). Telehealth uptake into prenatal care and provider attitudes during the COVID-19 pandemic in New York City: A quantitative and qualitative analysis. American Journal of Perinatology, 37(10), 1005-1014. https://doi.org/10.1055/s-0040-1712939

McCarthy, M., Duncan, J., \& Leigh, G. (2012). Telepractice: The Australian Experience in an International Context. Volta Review, 112(3). https://www.agbell.org/Portals/26/VoltaReview/112-3.pdf

McCarthy, M., Leigh, G., \& Arthur-Kelly, M. (2019a). Comparison of Caregiver Engagement in Telepractice and In-person Family-Centered Early Intervention. The Journal of Deaf Studies and Deaf Education, 25(1), 33-42. https://doi.org/10.1093/deafed/enz037

McCarthy, M., Leigh, G., \& Arthur-Kelly, M. (2019b). Telepractice delivery of family-centered early intervention for children who are deaf or hard of hearing: A scoping review. Journal of Telemedicine and Telecare, 25(4), 249-260. https://doi.org/10.1177/1357633X18755883

McCarthy, M., Leigh, G., \& Arthur-Kelly, M. (2020). Practitioners' self-assessment of family-centered practice in telepractice versus in-person early intervention. Journal of Deaf Studies and Deaf Education https://doi.org/10.1093/deafed/enaa028

MED-EL GmbH. (2020a). MED-EL Remote Lesson Kits. Retrieved from https://blog.medel.pro/?s=remote+lesson+kits.

MED-EL GmbH. (2020b). MED-EL Themed Lesson Kits. Retrieved from https://blog.medel.pro/tag/themed-lesson-kits/.

Moeller, M. P., Carr, G., Seaver, L., Stredler-Brown, A., \& Holzinger, D. (2013). Best Practices in family-centered early intervention for children who are Deaf or hard of hearing: An international consensus statement. The Journal of Deaf Studies and Deaf Education, 18(4), 429-445. https://doi.org/10.1093/deafed/ent034

Mohan, H. S., Anjum, A., \& Rao, P. K. S. (2017). A survey of telepractice in speech-language pathology and audiology in India. International Journal of Telerehabilitation, 9(2), 69-80. https://doi.org/10.5195/ijt.2017.6233

Olsen, S., Fiechtl, B., \& Rule, S. (2012). An evaluation of virtual home visits in early intervention: Feasibility of "virtual intervention." Volta Review, 112, 267-281. https://doi.org/10.17955/tvr.112.3.m.702

Olusanya, B. O. (2006). Early hearing detection and intervention in developing countries: Current status and prospects. Volta Review, 106(3).

Saile, T., \& Gregori, J. (2020). Masken und ihre akustischen Nebenwirkungen. Retrieved from https://www.audioinfos.de/neues-in-kurze/2028-masken-und-ihre-akustischen-nebenwirkungen.

Saunders, G. H., \& Roughley, A. (2020). Audiology in the time of COVID-19: Practices and opinions of audiologists in the UK. International Journal of Audiology, 1-8. https://doi.org/10.1080/14992027.2020.1814432

Sharma, S. D., Cushing, S. L., Papsin B. C., \& Gordon, K. A. (2020). Hearing and speech benefits of cochlear implantation in children: A review of the literature. International Journal of Pediatric Otorhinolaryngology 133, 109984 https://doi.org/10.1016/j.ijporl.2020.109984

Smith, A. C., Thomas, E., Snoswell, C. L., Haydon, H., Mehrotra, A., Clemensen, J., \& Caffery, L. J. (2020). Telehealth for global emergencies: Implications for coronavirus disease 2019 (COVID-19). Journal of Telemedicine and Telecare, 26(5), 309-313. https://doi.org/10.1177/1357633X20916567

Stredler-Brown, A. (2017). Examination of coaching behaviors used by providers when delivering early intervention via telehealth to families of children who are Deaf or hard of hearing. Perspectives of the ASHA Special Interest Groups, 2(9), 25-42. https://doi.org/10.1044/persp2.SIG9.25

Tohidast, S. A., Mansuri, B., Bagheri, R., \& Azimi, H. (2020). Provision of speech-language pathology services for the treatment of speech and language disorders in children during the COVID-19 pandemic: Problems, concerns, and solutions. International Journal of Pediatric Otorhinolaryngology 138, 110262. https://doi.org/10.1016/.i.jporl.2020.110262

United Nations. (2020). World economic situation and prospects 2020. Retrieved from https://doi.org/10.18356/ee1a3197-en.

Wales, D., Skinner, L., \& Hayman, M. (2017). The efficacy of telehealth-delivered speech and language intervention for primary school-age children: A systematic review. International Journal of Telerehabilitation, 9(1), 55-70. https://doi.org/10.5195/ijt.2017.6219

Yang, H.-W., Burke, M., Isaacs, S., Rios, K., Schraml-Block, K., Aleman-Tovar, J., Tompkins, J., \& Swartz, R. (2020). Family perspectives toward using telehealth in early intervention. Journal of Developmental and Physical Disabilities. https://doi.org/10.1007/s10882-020-09744-y

Yellowlees, P., Nakagawa, K., Pakyurek, M., Hanson, A., Elder, J., \& Kales, H. C. (2020). Rapid conversion of an outpatient psychiatric clinic to a 100\% virtual telepsychiatry clinic in response to COVID-19. Psychiatric Services, 71(7), 749-752. https://doi.org/10.1176/appi.ps.202000230 


\section{APPENDIX A}

\section{SURVEY QUESTIONS}

Table A1

Survey 1 Questions and Answer Categories

n Question

\begin{tabular}{|c|c|c|c|c|c|c|}
\hline 1 & Country & Open field & & & & \\
\hline 2 & I am... & $\begin{array}{l}\text { A speech } \\
\text { language } \\
\text { pathologist }\end{array}$ & $\begin{array}{l}\text { A teacher of the } \\
\text { Deaf }\end{array}$ & An audiologist & Other & \\
\hline 3 & $\begin{array}{l}\text { How many years' experience do you have delivering } \\
\text { in-person intervention to families with children who } \\
\text { are using hearing technology? }\end{array}$ & None & $\begin{array}{l}\text { Less than } 1 \\
\text { year }\end{array}$ & 1 to 2 years & 2 to 5 years & $\begin{array}{l}\text { More than } 5 \\
\text { years }\end{array}$ \\
\hline 4 & $\begin{array}{l}\text { How many years' experience do you have delivering } \\
\text { telepractice to families with children who are using } \\
\text { hearing technology? }\end{array}$ & None & $\begin{array}{l}\text { Less than } 1 \\
\text { year }\end{array}$ & 1 to 2 years & 2 to 5 years & $\begin{array}{l}\text { More than } 5 \\
\text { years }\end{array}$ \\
\hline 6 & $\begin{array}{l}\text { How often in a typical week are you providing in- } \\
\text { person intervention to families with children who are } \\
\text { using hearing technology? }\end{array}$ & $\begin{array}{l}\text { Less than } 1 \\
\text { session per } \\
\text { week }\end{array}$ & $\begin{array}{l}1 \text { session per } \\
\text { week }\end{array}$ & $\begin{array}{l}2-4 \text { sessions } \\
\text { per week }\end{array}$ & $\begin{array}{l}1 \text { session per } \\
\text { day }\end{array}$ & $\begin{array}{l}\text { Multiple } \\
\text { sessions per } \\
\text { day }\end{array}$ \\
\hline 7 & $\begin{array}{l}\text { How many families with children who are using } \\
\text { hearing technology do you provide services to via } \\
\text { telepractice? }\end{array}$ & 1 & $2-3$ & $4-6$ & $7-10$ & More than 10 \\
\hline
\end{tabular}

\section{Answer categories}




\section{Question}

8

How often in a typical week are you providing

telepractice intervention to families with children who

are using hearing technology?

9

In your practice do families receiving telepractice intervention get seen for therapy more often or less

often than families receiving in-person intervention?

\begin{tabular}{|l|l|l|l|l}
\hline 10 & $\begin{array}{l}\text { I can (or I think I could) effectively use the same } \\
\text { therapy resources for in-person and telepractice } \\
\text { sessions. }\end{array}$ \\
\hline
\end{tabular}

11

I have used the MED-EL Lesson kits in telepractice sessions.

\section{Answer categories}

\begin{tabular}{|c|c|c|c|c|c|}
\hline $\begin{array}{l}\text { Less than } 1 \\
\text { session per } \\
\text { week }\end{array}$ & $\begin{array}{l}1 \text { session per } \\
\text { week }\end{array}$ & $\begin{array}{l}2-4 \text { sessions } \\
\text { per week }\end{array}$ & $\begin{array}{l}1 \text { session per } \\
\text { day }\end{array}$ & $\begin{array}{l}\text { Multiple } \\
\text { sessions per } \\
\text { day }\end{array}$ & \\
\hline $\begin{array}{l}\text { My telepractice } \\
\text { does not } \\
\text { provide both } \\
\text { telepractice and } \\
\text { in-person } \\
\text { services }\end{array}$ & $\begin{array}{l}\text { Telepractice } \\
\text { families are } \\
\text { seen more often }\end{array}$ & $\begin{array}{l}\text { In-person } \\
\text { families are } \\
\text { seen more } \\
\text { often }\end{array}$ & $\begin{array}{l}\text { Both are } \\
\text { offered the } \\
\text { same } \\
\text { frequency of } \\
\text { service }\end{array}$ & I don't know & \\
\hline Strongly agree & Agree & Neutral & Disagree & $\begin{array}{l}\text { Strongly } \\
\text { disagree }\end{array}$ & Not sure \\
\hline Yes & No & $\begin{array}{l}\text { I am not familiar } \\
\text { with the MED- } \\
\text { EL Lesson Kits }\end{array}$ & & & \\
\hline
\end{tabular}

To what extent do you think the following impact the delivery of telepractice:

\begin{tabular}{|c|c|c|c|c|c|c|}
\hline $12 a$ & Set up cost to service provider & $\begin{array}{l}\text { Very significant } \\
\text { impact }\end{array}$ & $\begin{array}{l}\text { Significant } \\
\text { impact }\end{array}$ & Slight impact & $\begin{array}{l}\text { No significant } \\
\text { impact }\end{array}$ & Not sure \\
\hline $12 b$ & Set up cost to family & $\begin{array}{l}\text { Very significant } \\
\text { impact }\end{array}$ & $\begin{array}{l}\text { Significant } \\
\text { impact }\end{array}$ & Slight impact & $\begin{array}{l}\text { No significant } \\
\text { impact }\end{array}$ & Not sure \\
\hline
\end{tabular}




\begin{tabular}{|c|c|c|c|c|c|c|}
\hline \multirow{2}{*}{$\begin{array}{c}n \\
12 c\end{array}$} & \multirow{2}{*}{$\begin{array}{l}\text { Question } \\
\text { Ongoing cost to service provider }\end{array}$} & \multicolumn{5}{|c|}{ Answer categories } \\
\hline & & $\begin{array}{l}\text { Very significant } \\
\text { impact }\end{array}$ & $\begin{array}{l}\text { Significant } \\
\text { impact }\end{array}$ & Slight impact & $\begin{array}{l}\text { No significant } \\
\text { impact }\end{array}$ & Not sure \\
\hline $12 d$ & Ongoing cost to family & $\begin{array}{l}\text { Very significant } \\
\text { impact }\end{array}$ & $\begin{array}{l}\text { Significant } \\
\text { impact }\end{array}$ & Slight impact & $\begin{array}{l}\text { No significant } \\
\text { impact }\end{array}$ & Not sure \\
\hline $12 e$ & Connectivity (internet) issues & $\begin{array}{l}\text { Very significant } \\
\text { impact }\end{array}$ & $\begin{array}{l}\text { Significant } \\
\text { impact }\end{array}$ & Slight impact & $\begin{array}{l}\text { No significant } \\
\text { impact }\end{array}$ & Not sure \\
\hline $12 f$ & $\begin{array}{l}\text { Accessing or developing appropriate therapy } \\
\text { resources }\end{array}$ & $\begin{array}{l}\text { Very significant } \\
\text { impact }\end{array}$ & $\begin{array}{l}\text { Significant } \\
\text { impact }\end{array}$ & Slight impact & $\begin{array}{l}\text { No significant } \\
\text { impact }\end{array}$ & Not sure \\
\hline $12 g$ & Cost of therapy resources & $\begin{array}{l}\text { Very significant } \\
\text { impact }\end{array}$ & $\begin{array}{l}\text { Significant } \\
\text { impact }\end{array}$ & Slight impact & $\begin{array}{l}\text { No significant } \\
\text { impact }\end{array}$ & Not sure \\
\hline $12 \mathrm{~h}$ & Challenge of information sharing & $\begin{array}{l}\text { Very significant } \\
\text { impact }\end{array}$ & $\begin{array}{l}\text { Significant } \\
\text { impact }\end{array}$ & Slight impact & $\begin{array}{l}\text { No significant } \\
\text { impact }\end{array}$ & Not sure \\
\hline $12 \mathbf{i}$ & Therapy setting, location, environment & $\begin{array}{l}\text { Very significant } \\
\text { impact }\end{array}$ & $\begin{array}{l}\text { Significant } \\
\text { impact }\end{array}$ & Slight impact & $\begin{array}{l}\text { No significant } \\
\text { impact }\end{array}$ & Not sure \\
\hline $12 \mathrm{j}$ & Child attention management & $\begin{array}{l}\text { Very significant } \\
\text { impact }\end{array}$ & $\begin{array}{l}\text { Significant } \\
\text { impact }\end{array}$ & Slight impact & $\begin{array}{l}\text { No significant } \\
\text { impact }\end{array}$ & Not sure \\
\hline $12 k$ & Child behaviour management & $\begin{array}{l}\text { Very significant } \\
\text { impact }\end{array}$ & $\begin{array}{l}\text { Significant } \\
\text { impact }\end{array}$ & Slight impact & $\begin{array}{l}\text { No significant } \\
\text { impact }\end{array}$ & Not sure \\
\hline
\end{tabular}


Question

\begin{tabular}{|c|c|c|c|c|c|c|c|}
\hline 121 & Clinician completing telepractice training & $\begin{array}{l}\text { Very significant } \\
\text { impact }\end{array}$ & $\begin{array}{l}\text { Significant } \\
\text { impact }\end{array}$ & Slight impact & $\begin{array}{l}\text { No significant } \\
\text { impact }\end{array}$ & Not sure & \\
\hline $12 n$ & Clinician use of parent coaching strategies & $\begin{array}{l}\text { Very significant } \\
\text { impact }\end{array}$ & $\begin{array}{l}\text { Significant } \\
\text { impact }\end{array}$ & Slight impact & $\begin{array}{l}\text { No significant } \\
\text { impact }\end{array}$ & Not sure & \\
\hline 13 & $\begin{array}{l}\text { I feel as confident delivering intervention via } \\
\text { telepractice as I do with in-person lessons. }\end{array}$ & Strongly agree & Agree & Neutral & Disagree & $\begin{array}{l}\text { Strongly } \\
\text { disagree }\end{array}$ & Not sure \\
\hline 14 & Therapy outcomes from telepractice are likely to be: & $\begin{array}{l}\text { Poorer than in- } \\
\text { person } \\
\text { intervention }\end{array}$ & $\begin{array}{l}\text { The same as in- } \\
\text { person } \\
\text { intervention }\end{array}$ & $\begin{array}{l}\text { Better than } \\
\text { in-person } \\
\text { intervention }\end{array}$ & Not sure & & \\
\hline 15 & $\begin{array}{l}\text { Tell us about how you developed or are developing } \\
\text { your skills to deliver telepractice. }\end{array}$ & Open field & & & & & \\
\hline 16 & $\begin{array}{l}\text { How would you describe the process of accessing } \\
\text { information to develop your skills in delivering } \\
\text { telepractice? }\end{array}$ & Very easy & Easy & Neutral & Difficult & Very difficult & \\
\hline 17 & How can MED-EL help you in delivering telepractice? & Open field & & & & & \\
\hline
\end{tabular}


Table A2

Survey 2 Questions and Answer Categories

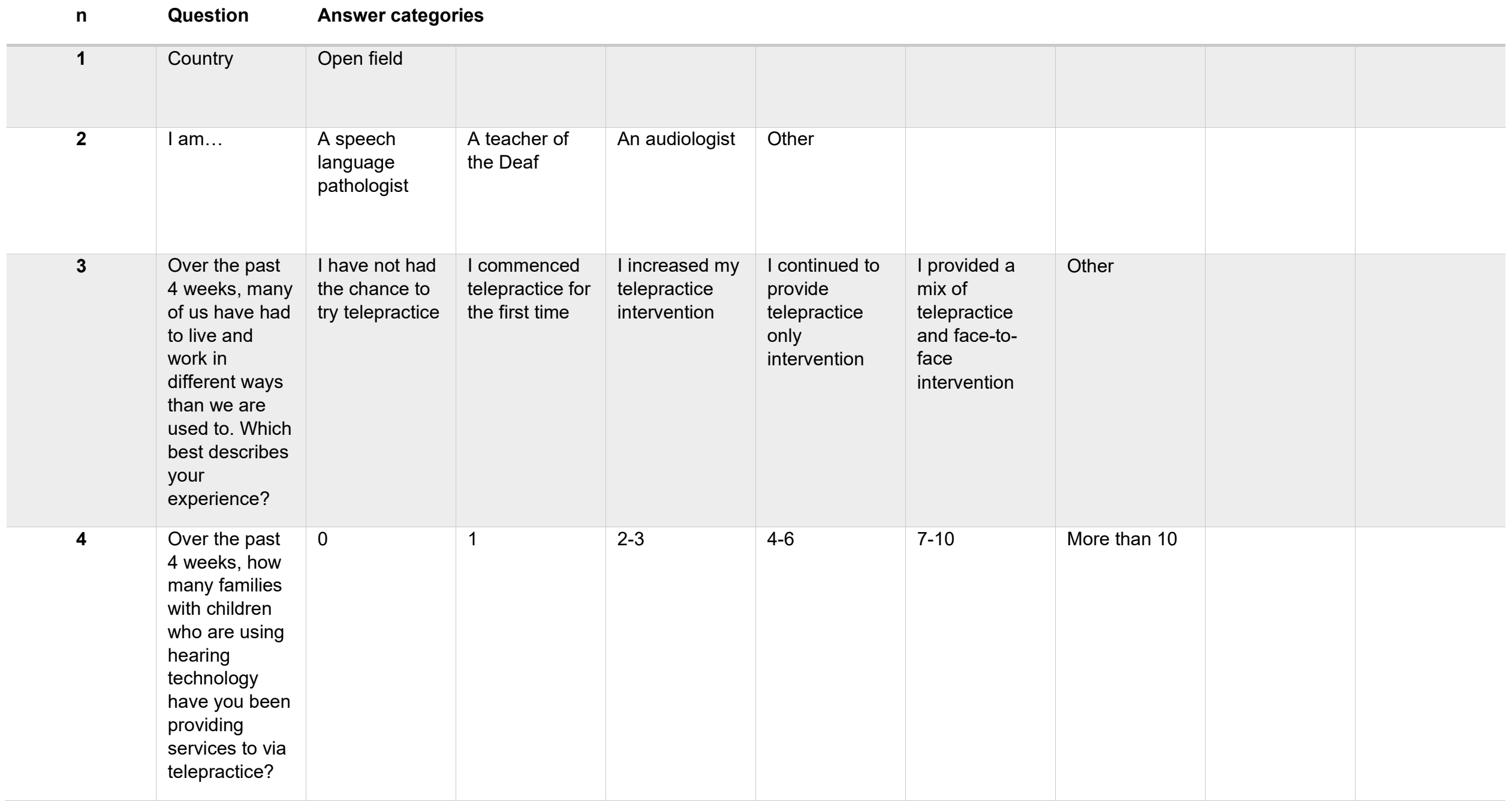




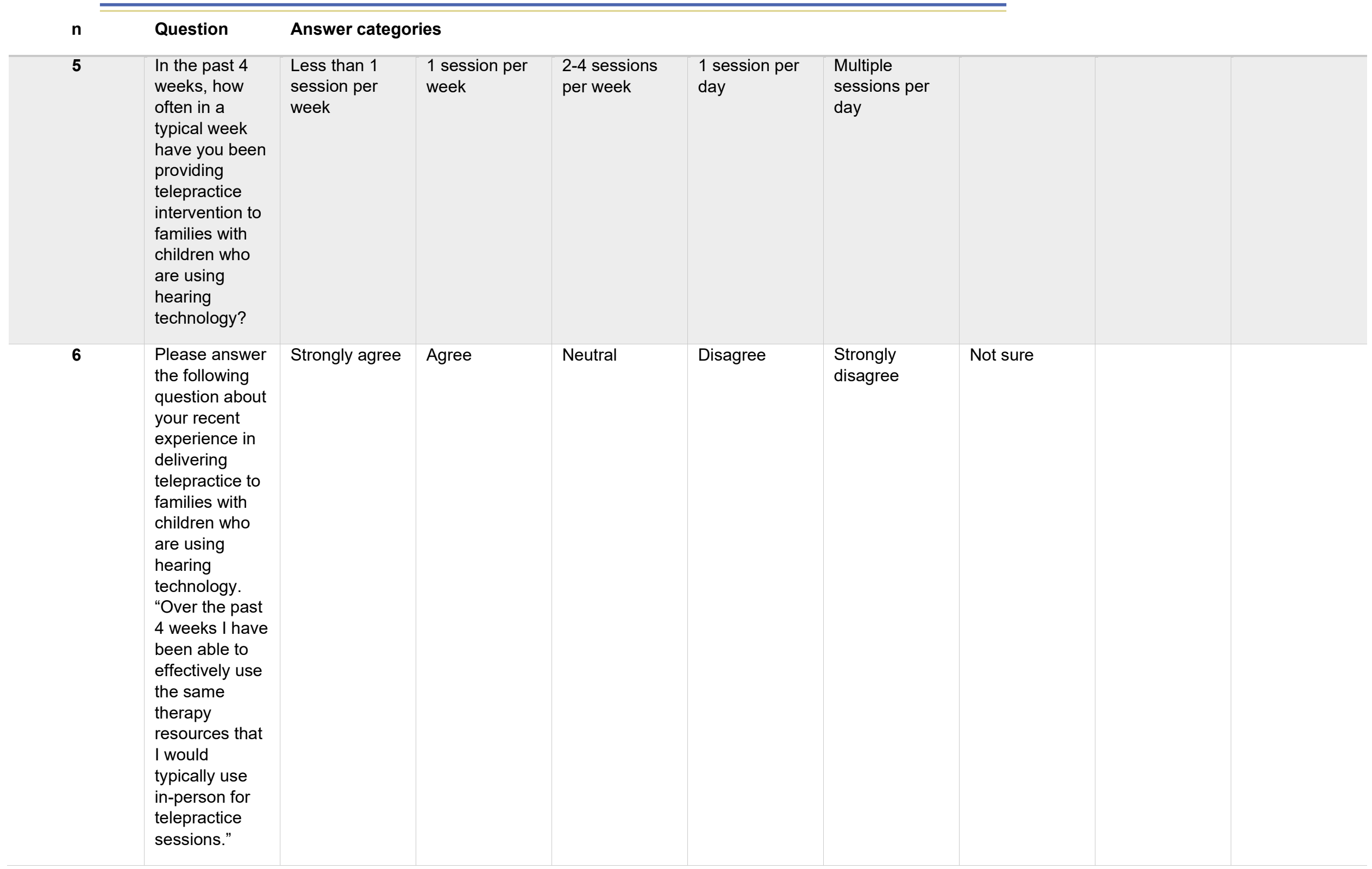




\begin{tabular}{|c|c|c|c|c|c|c|c|c|c|}
\hline $\mathbf{n}$ & Question & Answer categ & ies & & & & & & \\
\hline 7 & $\begin{array}{l}\text { How often did } \\
\text { you use the } \\
\text { MED-EL } \\
\text { Remote } \\
\text { Lesson Kits for } \\
\text { telepractice? }\end{array}$ & $\begin{array}{l}\text { I did not use } \\
\text { them }\end{array}$ & $\begin{array}{l}\text { Less than once } \\
\text { a week }\end{array}$ & Weekly & Daily & & & & \\
\hline 8 & $\begin{array}{l}\text { Please rate the } \\
\text { following } \\
\text { elements of } \\
\text { the Remote } \\
\text { Lesson Kits } \\
\text { (very useful, } \\
\text { useful, neutral, } \\
\text { not so useful, } \\
\text { not useful at } \\
\text { all, I didn't look } \\
\text { at it). }\end{array}$ & $\begin{array}{l}\text { Learn about } \\
\text { the MED-EL } \\
\text { remote lesson } \\
\text { kits (page 1) }\end{array}$ & $\begin{array}{l}\text { Getting started } \\
\text { with remote } \\
\text { therapy (page } \\
\text { 2) }\end{array}$ & $\begin{array}{l}\text { Key strategies } \\
\text { for developing } \\
\text { listening skills } \\
\text { (pages } 3,4 \text { ) }\end{array}$ & $\begin{array}{l}\text { Learn about } \\
\text { the levels } \\
\text { (page } 5 \text { ) }\end{array}$ & $\begin{array}{l}\text { The Lesson } \\
\text { Plan (page 6) }\end{array}$ & $\begin{array}{l}\text { The therapist } \\
\text { notes for each } \\
\text { activity }\end{array}$ & $\begin{array}{l}\text { The printable } \\
\text { resources }\end{array}$ & $\begin{array}{l}\text { The slide } \\
\text { decks (PPTs) }\end{array}$ \\
\hline 9 & $\begin{array}{l}\text { Tell us how } \\
\text { you used the } \\
\text { Remote } \\
\text { Lesson Kits. } \\
\text { Tick all that } \\
\text { apply. }\end{array}$ & $\begin{array}{l}\text { I didn't use } \\
\text { them }\end{array}$ & $\begin{array}{l}\text { I printed and } \\
\text { posted the } \\
\text { resources to } \\
\text { families }\end{array}$ & $\begin{array}{l}\text { I emailed } \\
\text { resources and } \\
\text { families printed } \\
\text { them }\end{array}$ & $\begin{array}{l}\text { I shared } \\
\text { therapist notes } \\
\text { with families }\end{array}$ & $\begin{array}{l}\text { I screen- } \\
\text { shared the } \\
\text { pdfs }\end{array}$ & $\begin{array}{l}\text { I screen- } \\
\text { shared the } \\
\text { slide decks }\end{array}$ & $\begin{array}{l}\text { Families } \\
\text { loaded the } \\
\text { slide deck on } \\
\text { their device }\end{array}$ & Other \\
\hline 10 & $\begin{array}{l}\text { What would } \\
\text { have made } \\
\text { using the } \\
\text { Remote } \\
\text { Lesson Kits } \\
\text { easier or more } \\
\text { practical for } \\
\text { you? }\end{array}$ & Open field & & & & & & & \\
\hline
\end{tabular}


n

\section{Question Answer categories}

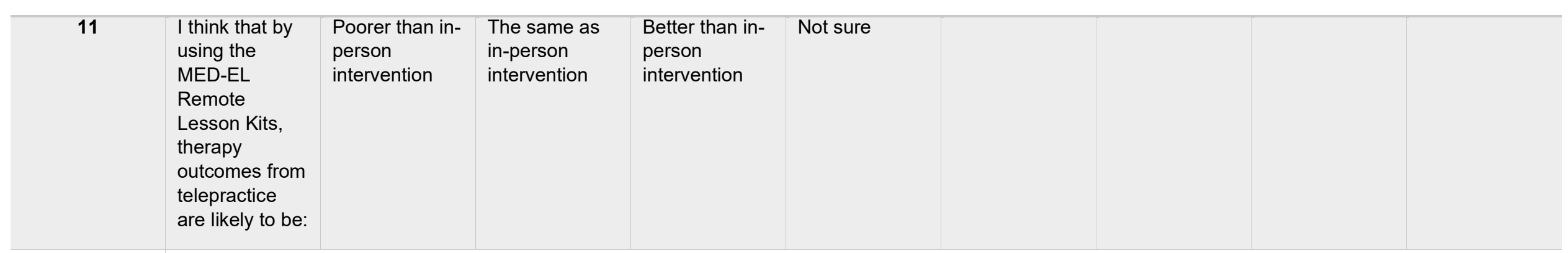

12 To what extent did using the MED-EL Remote Lesson Kits have an impact on the delivery of telepractice:

$12 \mathrm{a}$

Set up cost to
service
provider

$12 b$

Set up cost to

family

\section{Ongoing cost}

to service

provider

$12 d$

Ongoing cost

to family

$12 e$

Connectivity
(internet)
issues

$12 f$

Accessing or

Very positive
impact

Very positive

impact

Very positive

impact

Very positive

impact

\section{Very positive}

impact

developing

appropriate

therapy

resources

\section{Positive impact No impact}

Positive impact No impact

Positive impact

Positive impact No impact

Negative

impact

Negative

impact

Negative

impact

Negative

impact

\begin{tabular}{|l|l}
$\begin{array}{l}\text { Very negative } \\
\text { impact }\end{array}$ & Not sure \\
$\begin{array}{l}\text { Very negative } \\
\text { impact }\end{array}$ & Not sure \\
\hline $\begin{array}{l}\text { Very negative } \\
\text { impact }\end{array}$ & Not sure \\
\hline $\begin{array}{l}\text { Very negative } \\
\text { impact }\end{array}$ & Not sure \\
\hline $\begin{array}{l}\text { Very negative } \\
\text { impact }\end{array}$ & Not sure \\
\hline $\begin{array}{l}\text { Very negative } \\
\text { impact }\end{array}$ & Not sure \\
\hline
\end{tabular}




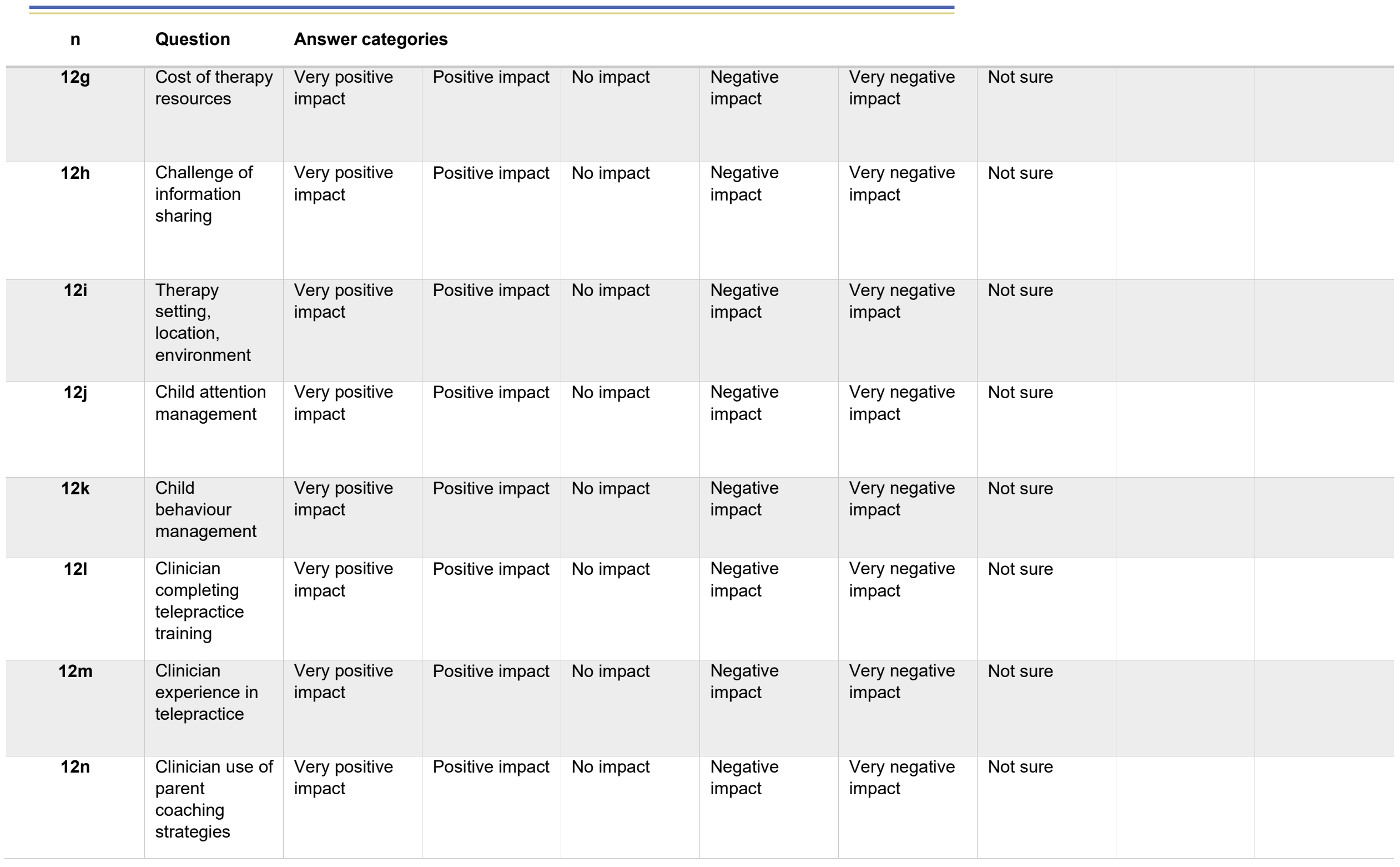


n

\section{Question Answer categories}

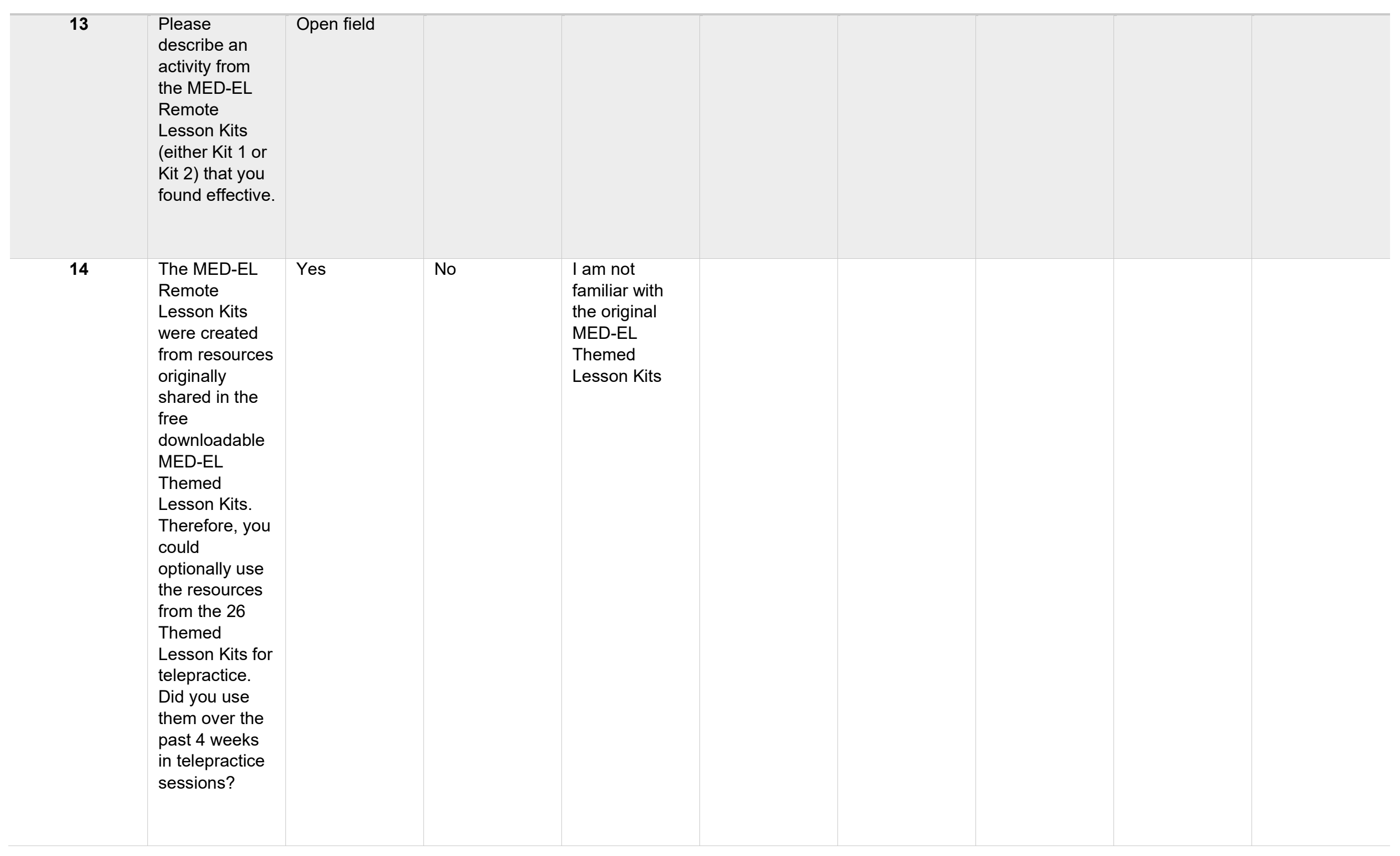




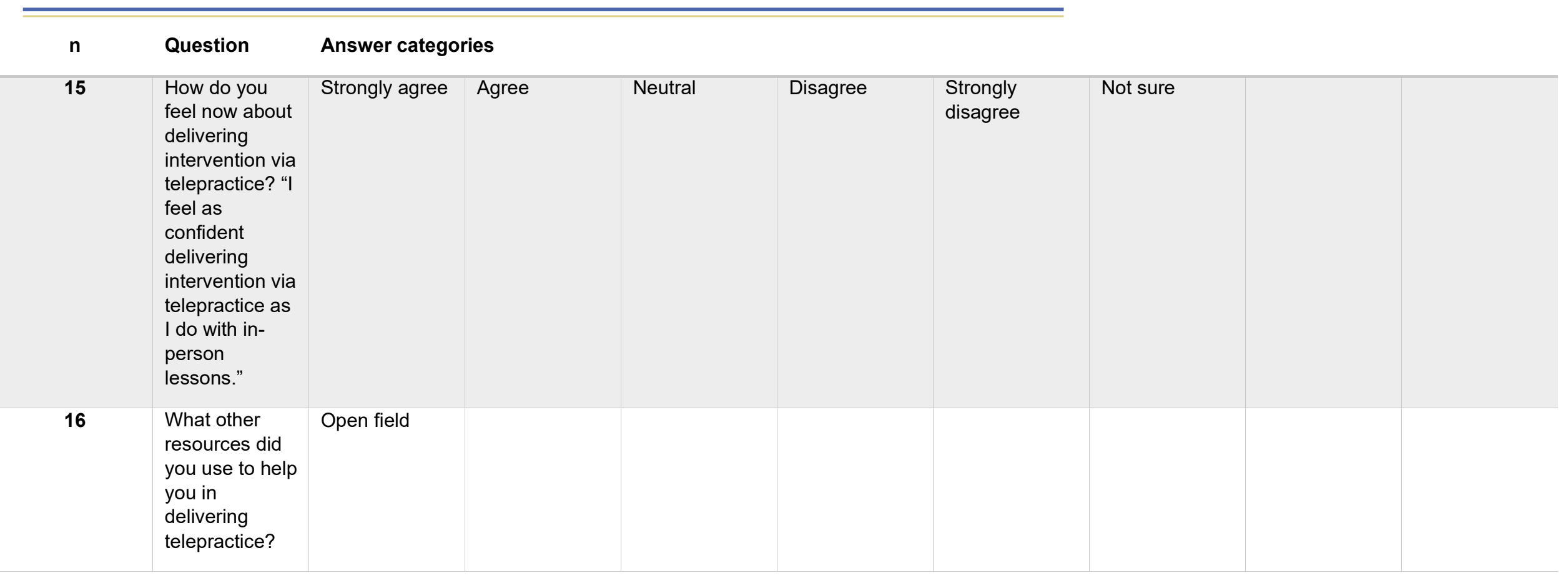




\section{APPENDIX B}

\section{COLLAPSED ANSWER CATEGORIES}

\begin{tabular}{|c|c|c|c|}
\hline Survey & Question & Original answer categories & Collapsed answer categories \\
\hline \multirow[t]{7}{*}{1} & $3 ; 4$ & $\begin{array}{l}\text { None } \\
\text { Less than } 1 \text { year } \\
1 \text { to } 2 \text { years } \\
2 \text { to } 5 \text { years } \\
\text { More than } 5 \text { years }\end{array}$ & $\begin{array}{l}\text { None } \\
\text { Less than } 1 \text { year } \\
\text { More than } 1 \text { year }\end{array}$ \\
\hline & $10 ; 13$ & $\begin{array}{l}\text { Strongly agree } \\
\text { Agree } \\
\text { Neutral } \\
\text { Disagree } \\
\text { Strongly disagree } \\
\text { Not sure }\end{array}$ & $\begin{array}{l}\text { Agree } \\
\text { Neutral } \\
\text { Disagree } \\
\text { Not sure }\end{array}$ \\
\hline & 12 & $\begin{array}{l}\text { Very significant impact } \\
\text { Significant impact } \\
\text { Slight impact } \\
\text { No significant impact } \\
\text { Not sure }\end{array}$ & $\begin{array}{l}\text { Positive impact } \\
\text { Slight impact } \\
\text { No significant impact } \\
\text { Not sure }\end{array}$ \\
\hline & & $\begin{array}{l}\text { Child behaviour management } \\
\text { Child attention management }\end{array}$ & Child management \\
\hline & & $\begin{array}{l}\text { Setup cost to family } \\
\text { Ongoing cost to family }\end{array}$ & Total cost to family \\
\hline & & $\begin{array}{l}\text { Setup cost to service provider } \\
\text { Ongoing cost to service provider }\end{array}$ & Total cost to service provider \\
\hline & 16 & $\begin{array}{l}\text { Very easy } \\
\text { Easy } \\
\text { Neutral } \\
\text { Difficult } \\
\text { Very difficult }\end{array}$ & $\begin{array}{l}\text { Easy } \\
\text { Neutral } \\
\text { Difficult }\end{array}$ \\
\hline 2 & $6 ; 15$ & $\begin{array}{l}\text { Strongly agree } \\
\text { Agree } \\
\text { Neutral } \\
\text { Disagree } \\
\text { Strongly disagree } \\
\text { Not sure }\end{array}$ & $\begin{array}{l}\text { Agree } \\
\text { Neutral } \\
\text { Disagree } \\
\text { Not sure }\end{array}$ \\
\hline
\end{tabular}




\begin{tabular}{|c|c|c|c|}
\hline Survey & Question & Original answer categories & Collapsed answer categories \\
\hline & \multirow[t]{4}{*}{12} & $\begin{array}{l}\text { Very positive impact } \\
\text { Positive impact } \\
\text { No impact } \\
\text { Negative impact } \\
\text { Very negative impact } \\
\text { Not sure }\end{array}$ & $\begin{array}{l}\text { Positive impact } \\
\text { No impact } \\
\text { Negative impact } \\
\text { Not sure }\end{array}$ \\
\hline & & $\begin{array}{l}\text { Child behaviour management } \\
\text { Child attention management }\end{array}$ & Child management \\
\hline & & $\begin{array}{l}\text { Setup cost to family } \\
\text { Ongoing cost to family }\end{array}$ & Total cost to family \\
\hline & & $\begin{array}{l}\text { Setup cost to service provider } \\
\text { Ongoing cost to service provider }\end{array}$ & Total cost to service provider \\
\hline
\end{tabular}

